\title{
Leptin and energy expenditure
}

Citation for published version (APA):

Hukshorn, C. J., \& Saris, W. H. (2004). Leptin and energy expenditure. Current Opinion in Clinical Nutrition and Metabolic Care, 7(6), 629-633. https://doi.org/10.1097/00075197-200411000-00007

Document status and date:

Published: 01/01/2004

DOI:

10.1097/00075197-200411000-00007

Document Version:

Publisher's PDF, also known as Version of record

\section{Please check the document version of this publication:}

- A submitted manuscript is the version of the article upon submission and before peer-review. There can be important differences between the submitted version and the official published version of record.

People interested in the research are advised to contact the author for the final version of the publication, or visit the DOI to the publisher's website.

- The final author version and the galley proof are versions of the publication after peer review.

- The final published version features the final layout of the paper including the volume, issue and page numbers.

Link to publication

\footnotetext{
General rights rights.

- You may freely distribute the URL identifying the publication in the public portal. please follow below link for the End User Agreement:

www.umlib.nl/taverne-license

Take down policy

If you believe that this document breaches copyright please contact us at:

repository@maastrichtuniversity.nl

providing details and we will investigate your claim.
}

Copyright and moral rights for the publications made accessible in the public portal are retained by the authors and/or other copyright owners and it is a condition of accessing publications that users recognise and abide by the legal requirements associated with these

- Users may download and print one copy of any publication from the public portal for the purpose of private study or research.

- You may not further distribute the material or use it for any profit-making activity or commercial gain

If the publication is distributed under the terms of Article $25 \mathrm{fa}$ of the Dutch Copyright Act, indicated by the "Taverne" license above, 


\section{Leptin and energy expenditure}

\section{Chris J. Hukshorn and Wim H.M. Saris}

\section{Purpose of review}

A fundamental advance in our understanding of endocrine control of energy balance and body weight came with the discovery of the adipocyte-derived hormone leptin. The leptin pathway appeared to be the long-sought peripheral signal pathway from the adipose tissue to the brain involved in the regulation of feeding and energy balance.

\section{Recent findings}

Initially, leptin was considered to function as the long-sought antiobesity hormone. According to this hypothesis, rising concentrations of leptin with increasing adiposity would generate a signal to reduce food intake and increase energy expenditure in order to limit further weight gain. However, widespread resistance to the proposed antiobesity action of leptin is observed in humans, which might reflect the fact that the inability to store energy efficiently at times of abundance is evolutionarily disadvantageous. According to this alternative view, falling leptin concentrations observed during fasting act as a peripheral signal of starvation, which serves to conserve energy in the face of limited reserves. However, leptin administration failed to blunt the changes in energy expenditure during severe energy restrictions in several clinical studies. In addition, leptin therapy in several different human low-leptin states failed to affect energy expenditure in recent studies.

\section{Summary}

Increasing evidence from human studies suggests that leptin predominantly influences the human energy balance through appetite but appears not to be involved in regulating energy expenditure. None of the expected factors such as resting metabolic rate, total diurnal energy expenditure or dietary induced thermogenesis was related to blood leptin concentrations.

\section{Keywords}

appetite, energy expenditure, human, leptin

Curr Opin Clin Nutr Metab Care 7:629-633. (c) 2004 Lippincott Williams \& Wilkins.

Nutrition and Toxicology Research Institute Maastricht (NUTRIM), Department of Human Biology, Maastricht University, Maastricht, The Netherlands

Correspondence to C.J. Hukshorn, Department of Human Biology, Maastricht University, PO Box 616, 6200 MD Maastricht, The Netherlands

Tel: +31 43388 2112; fax: +31 43367 0976; e-mail: c.hukshorn@hb.unimaas.n

Current Opinion in Clinical Nutrition and Metabolic Care 2004, 7:629-633

Abbreviations

PEG-OB pegylated human recombinant leptin SNS sympathetic nervous system

(C) 2004 Lippincott Williams \& Wilkins 1363-1950

\section{Introduction}

The discovery of the hormone leptin (also known as OB protein) by Zhang and colleagues in December 1994 had an enormous impact both in understanding the molecular control of energy balance and in attitudes to the scientific study of obesity [1]. Over the last 9 years more than 4500 papers have been published on leptin (from the Greek leptos, meaning thin), leading to an ever-advancing body of knowledge. The leptin pathway appeared to be the long-sought peripheral signal pathway from the adipose tissue to the brain involved in the regulation of feeding and energy balance.

In 1950, a spontaneous recessive genetic mutation resulting in profound obesity and diabetes was identified in an inbred mice colony [2]. Shortly after the discovery of the ob/ob mouse, additional recessively inherited forms of obesity, called the diabetes $(d b / d b)$ mouse and the Zucker (fa/fa) rat were described [3,4]. Despite being genetically different, these animals expressed phenotypically identical characteristics, such as massive obesity of early onset due both to hyperphagia and reduced energy expenditure. In addition, these rodents exhibited hypothermia, type 2 diabetes, dyslipidemia, hypercortisolemia, decreased immune function and infertility due to hypogonadotropic hypogonadism. In the 1970s, classic parabiosis experiments, in which the circulations of $o b / o b$ and $d b /$ $d b$ mice were connected, resulted in weight loss due to hypophagia and finally cachexia and death in the ob/ob mouse, while retention of increased food intake and weight in their $d b / d b$ pair-mates was observed $[5,6]$. These results led to the hypothesis that the $o b$ gene encoded a circulating substance that affected the energy balance and consequently body weight control. Also, it was suggested that the receptor of this unknown substance was encoded by, or under control of, the $d b$ gene. It was not until 1994 that this hypothesis could be verified and a new endocrine system was revealed.

\section{Leptin, an antiobesity hormone?}

Soon after the cloning of the $o b$ gene, leptin-deficient $o b /$ ob mice were injected with recombinant leptin, which led to weight loss due to decreased food intake and increased energy expenditure [1,7-9]. This outcome supported the original concept that leptin's function was to control weight gain by reducing food intake and increasing energy expenditure as its concentration in blood rises with increasing adiposity. This impressive 
effect of leptin administration to $o b / o b$ mice raised expectations that human obesity could also be a (relative) leptin-deficient state that could possibly be treated with exogenous leptin. Several early population studies, however, failed to demonstrate mutations in the human gene encoding for leptin [10-12]. In contrast, after the development of radioimmunnoassays for human leptin, it became clear that in the majority of obese individuals elevated serum leptin levels are found [13], which apparently failed to prevent obesity. From these results, the hypothesis of leptin resistance or reduced sensitivity to leptin in human obesity emerged, comparable to insulin resistance in type 2 diabetes $[14,15]$. The observation that higher doses of recombinant leptin are required to affect feeding behavior, metabolism, and body fat in diet-induced obese mice compared with normal mice supported this concept of leptin resistance [9]. These early results suggested the possibility that high therapeutical doses of human recombinant leptin may be able to overcome the presumed increased leptin resistance present in obese individuals and result in reduction in body weight by reducing food intake and increasing energy expenditure.

To test this hypothesis, we studied the effect of weekly administration of long-acting pegylated human recombinant leptin (PEG-OB) on body weight loss and energy expenditure in obese men during mild hypocaloric conditions for 12 weeks. Treatment with PEG-OB sustained elevated levels of both PEG-OB and endogenous leptin and increased post-absorptive satiety throughout the treatment period without an effect on weight loss [16]. Despite sustained elevated levels of both PEG-OB and leptin throughout the treatment period, no effect was observed on weight loss or energy expenditure measured by a respiration chamber [17]. This outcome was in line with the results of several other clinical studies which showed that even supraphysiological leptin concentrations failed to significantly affect body weight in humans during weight maintenance or mild hypocaloric conditions $[18,19]$. In particular, no effect was observed on energy expenditure measured by indirect calorimetry [18]. Thus, it is unlikely that in humans leptin plays a role analogous to that observed in rodents, in which it is involved in acute and chronic adaptation of energy intake and energy expenditure.

\section{Leptin, a starvation hormone?}

The outcome of these clinical studies demonstrated that high leptin concentrations failed to significantly affect body weight, which implicates that humans are highly leptin resistant. This observation was, however, consistent with an alternative view of the physiological role of leptin, which emerged in 1998 [20,21]. The group of Flier hypothesized that the widespread occurrence of leptin resistance [22-24] might reflect the fact that the inability to store energy efficiently at times of abundance is evolutionarily disadvantageous. These investigators postulated that the falling concentration of leptin during starvation and its effects may constitute part of the thrifty genotype, a set of genes thought to promote survival during periods of insufficient energy intake in human evolution by increasing the efficiency of energy storage. The fact that during starvation leptin levels drop rapidly and out of proportion to body adiposity changes appears to support this hypothesis $[25,26]$. In this updated thrifty genotype concept, the drop in leptin concentrations during periods of limited energy intake might signal the brain to initiate the complex neural, metabolic, neuroendocrine, and behavioral responses thought to have survival value in periods of inadequate energy intake. In addition, this concept suggests that an effective adipostatic role of leptin would subvert the thrifty genotype by limiting the capacity of energy storage during periods of abundance, which would result in reduced survival in subsequent periods of food shortages. Stated differently, evolution would favor resistance to leptin action (leptin resistance) when leptin concentrations are rising or high during periods of sufficient energy intake/storage. Furthermore, they speculated that the shape of the biological doseresponse curve of leptin may depend on the conditions in which a certain species evolved.

An important clue suggesting that leptin might be involved in the regulation of the adaptations during starvation emerged with the observation that leptindeficient $o b / o b$ mice possess many characteristics similar to those during starvation. The genetically obese $o b / o b$ mouse, which lacks leptin, exhibits all adaptive physiological mechanisms appropriate for food scarcity even when it has free access to food [21]. The administration of leptin reversed these adaptations, such as low body temperature (topor), reductions in thyroid function and sympathetic nervous system (SNS) activity, hence raising energy expenditure. A classic replacement study preventing the characteristic fall in leptin during fasting blunted the activation of these neuroendocrine axes and also prevented hypothermia which also increased energy expenditure [27,28]. However, leptin treatment of normal mice fed ad libitum only prevents the decrease in energy expenditure that would normally occur with the leptin-induced reduction in food intake [29].

An indication suggesting that leptin could play an important role in the recognition of an early derailment of energy homeostasis and additional physiological functions such as reproduction can be derived from some observational studies in athletes. So far studies evaluating whether exercise per se or energy deficiency is the critical factor in the regulation of leptin is limited. 
Van Aggel-Leijssen et al. [30] showed that acute exercise decreased the nocturnal peak and average $24 \mathrm{~h}$ plasma leptin concentration. Positive or negative energy balance gave a much higher fluctuation. A short-term training program (12 weeks) did not influence leptin levels corrected for changes in fat mass [31]. In a long-term training program (16 months), however, a significant inverse relation was found between leptin levels and hours of training corrected for changes in insulin and body fat percentage [32]. In an elegant designed study, Hilton and Loucks [33] dissected the exercise stress from the energy availability. Low-energy availability profoundly suppressed the $24 \mathrm{~h}$ amplitude of the diurnal rhythm of leptin when exercise had no effect. The effect of low-energy availability caused by increased exercise energy expenditure was smaller than that caused by dietary restriction. The study demonstrated the importance of energy availability in comparison to exercise stress on leptin as an important biomarker of energy homeostasis.

The hypothesis proposed by Flier et al. provided an explanation for the ineffectiveness of a high-dose PEG$\mathrm{OB}$ in our obese individuals on a mild hypocaloric diet as well for the fairly moderate results of the Heymsfield trial [19]. Furthermore, an extension of this hypothesis is that exogenous leptin should affect energy regulation when administrated during severe energy restriction. Therefore, to test this hypothesis, we executed another randomized, double-blind, and placebo-controlled study to investigate whether elevated leptin levels using PEG-OB affected weight loss, changes in energy expenditure, and appetite, during semistarvation induced by a very low calorie diet in healthy overweight male volunteers. Weekly subcutaneous administration of PEG-OB led to significant additional weight loss and reductions in appetite after 6 weeks of treatment and severe energy restriction, but did not affect changes in energy expenditure measured by indirect calorimetry [ $\left.34^{\bullet}\right]$.

In contrast to rodents, exogenous leptin in our study did not prevent or blunt the physiological fall in energy expenditure, which normally occurs during food deprivation. Two major factors reducing energy expenditure during fasting are the inhibition of SNS activity and the drop in thyroid hormones. Both fasting-induced effects were blunted in rodents treated with leptin [27,35]. Moreover, administration of leptin directly into the brains of rhesus monkeys acutely activated the SNS, suggesting that leptin may also influence energy expenditure in these nonhuman primates [36]. The fact that PEG-OB administration did not disinhibit SNS activity or prevent the fall in thyroid hormones might account for the absence of a stimulatory effect on energy expenditure in this human study [37]. In agreement with our findings, recombinant replacement therapy during short-term starvation in healthy men did not significantly alter the changes in energy expenditure [ $\left.38^{\bullet}\right]$. Another study, however, reported a reversal of the effects of sustained weight reduction on energy expenditure by a low dose of exogenous leptin [39].

\section{Leptin replacement in human leptin- deficiency states}

The findings of this study are consistent with the characteristics of homozygous human patients with total leptin deficiency or nonfunctional leptin receptors. These rare and very obese individuals have been shown to have a normal core temperature and normal resting energy expenditure but are markedly hyperphagic [4043]. In addition, mice heterozygous for the $o b$ gene $[44,45]$ and individuals who are genetically partially deficient in leptin [46] appear to be associated with an intermediate phenotype. Daily subcutaneous human recombinant leptin treatment of three children with a mutated $o b$ gene caused rapid and progressive reductions in body weight. This weight loss was mainly due to reductions in food intake as a result of decreased appetite and food-seeking behavior. However, leptin therapy in two congenital leptin-deficient children failed to affect basal metabolic rate or free-living energy expenditure (measured using doubly labeled water) who were both adjusted for lean body mass [47].

Several other syndromes have been associated with very low leptin levels. Recently, two siblings with RabsonMendenhall syndrome (severe insulin resistance and presumed insulin receptor mutations and low leptin levels) were treated with recombinant human leptin for 10 months. Resting energy expenditure (and lean body mass) remained stable during leptin treatment $\left[48^{\circ}\right]$.

Leptin-replacement therapy in patients with lipodystrophy and very low leptin levels has led to a decrease in resting metabolic rate most likely secondary to weight loss [49,50]. A major drawback of some studies, however, is the fact that the changes in energy expenditure are not adjusted for changes in lean body mass over the treatment period.

\section{Conclusion}

In summary, in humans, increasing evidence to date suggests that leptin predominantly influences the human energy balance through appetite but appears not to be involved in regulating energy expenditure. Both animal and human studies indicate that low or falling leptin levels (as observed during fasting) act as a peripheral signal of starvation, which subsequently increases appetite thereby ensuring survival of the species. At the other end of the spectrum, resistance to the proposed antiobesity action of high or rising leptin levels is 
observed in both animals and humans. Contrary to rodents, even supra-physiological leptin concentrations reached during several clinical trials failed to affect the human energy balance including energy expenditure. This widespread occurrence of leptin resistance could reflect the fact that the inability to store energy efficiently at times of abundance is evolutionarily disadvantageous.

\section{References and recommended reading}

Papers of particular interest, published within the annual period of review, have been highlighted as:

- of special interest

- of outstanding interest

1 Zhang $\mathrm{Y}$, Proenca $\mathrm{R}$, Maffei M, et al. Positional cloning of the mouse obese gene and its human homologue. Nature 1994; 372:425-432.

2 Ingalls AM, Dickie MM, Snell GD. Obese, new mutation in house mouse. J Hered 1950; 41:317-318.

3 Hummel KP, Dickie MM, Coleman DL. Diabetes, a new mutation in the mouse. Science 1966; 153:1127-1128.

4 Zucker LM, Zucker TF. Fatty, a new mutation in the rat. J Hered 1961; 52:275-278.

5 Coleman DL. Effects of parabiosis of obese with diabetes and normal mice. Diabetologia 1973; 9:294-298.

6 Coleman DL. Obese and diabetes: two mutant genes causing diabetesobesity syndromes in mice. Diabetologia 1978; 14:141-148.

7 Pelleymounter MA, Cullen MJ, Baker MB, et al. Effects of the obese gene product on body weight regulation in ob/ob mice. Science 1995; 269:540543.

8 Halaas JL, Gajiwala KS, Maffei M, et al. Weight-reducing effects of the plasma protein encoded by the obese gene. Science 1995; 269:543-546.

9 Campfield LA, Smith FJ, Guisez Y, et al. Recombinant mouse OB protein: evidence for a peripheral signal linking adiposity and central neural networks. Science 1995; 269:546-549.

10 Maffei M, Stoffel M, Barone M, et al. Absence of mutations in the human OB gene in obese/diabetic subjects. Diabetes 1996; 45:679-682.

11 Niki T, Mori H, Tamori Y, et al. Human obese gene: molecular screening in Japanese and Asian Indian NIDDM patients associated with obesity. Diabetes 1996; 45:675-678.

12 Considine RV, Considine EL, Williams CJ, et al. Evidence against either a premature stop codon or the absence of obese gene mRNA in human obesity. J Clin Invest 1995; 95:2986-2988.

13 Considine RV, Sinha MK, Heiman ML, et al. Serum immunoreactive-leptin concentrations in normal-weight and obese humans. N Engl J Med 1996; 334:292-295.

14 Campfield LA, Smith FJ, Burn P. OB protein: a hormonal controller of central neural network mediating behavioral, metabolic and neuro endocrine responses. Endocrinol Metab 1997; 4:81-102.

15 Campfield LA, Smith FJ. Overview: neurobiology of OB protein (leptin). Proc Nutr Soc 1998; 57:429-440.

16 Westerterp-Plantenga MS, Saris WH, Hukshorn CJ, Campfield LA. Effects of weekly administration of pegylated recombinant human $\mathrm{OB}$ protein on appetite profile and energy metabolism in obese men. Am J Clin Nutr 2001; 74:426-434.

17 Hukshorn CJ, Saris WHM, Westerterp Plantenga MS, et al. Weekly subcutaneous pegylated recombinant native human leptin (PEG-OB) administration in obese men. J Clin Endocrinol Metab 2000; 85:4003-4009.

18 Mackintosh RM, Hirsch J. The effects of leptin administration in non-obese human subjects. Obes Res 2001; 9:462-469.

19 Heymsfield SB, Greenberg AS, Fujioka K, et al. Recombinant leptin for weight loss in obese and lean adults: a randomized, controlled, doseescalation trial. JAMA 1999; 282:1568-1575.

20 Flier JS. Clinical review 94: what's in a name? In search of leptin's physiologic role. J Clin Endocrinol Metab 1998; 83:1407-1413.
21 Himms-Hagen J. Physiological roles of the leptin endocrine system: differences between mice and humans. Crit Rev Clin Lab Sci 1999; 36:575-655.

22 Van Heek M, Compton DS, France CF, et al. Diet-induced obese mice develop peripheral, but not central, resistance to leptin. J Clin Invest 1997; 99:385-390.

23 Frederich RC, Hamann A, Anderson S, et al. Leptin levels reflect body lipid content in mice: evidence for diet-induced resistance to leptin action. Nat Med 1995; 1:1311-1314.

24 Caro JF, Kolaczynski JW, Nyce MR, et al. Decreased cerebrospinal-fluid/ serum leptin ratio in obesity: a possible mechanism for leptin resistance. Lancet 1996; 348:159-161.

25 Frederich RC, Lollmann B, Hamann A, et al. Expression of ob mRNA and its encoded protein in rodents: impact of nutrition and obesity. J Clin Invest 1995; 96:1658-1663.

26 Boden G, Chen X, Mozzoli M, Ryan I. Effect of fasting on serum leptin in normal human subjects. J Clin Endocrinol Metab 1996; 81:3419-3423.

27 Ahima RS, Prabakaran D, Mantzoros C, et al. Role of leptin in the neuroendocrine response to fasting. Nature 1996; 382:250-252.

28 Doring H, Schwarzer K, Nuesslein-Hildesheim B, Schmidt I. Leptin selectively increases energy expenditure of food-restricted lean mice. Int J Obes Relat Metab Disord 1998; 22:83-88.

29 Halaas JL, Boozer C, Blair West J, et al. Physiological response to long-term peripheral and central leptin infusion in lean and obese mice. Proc Natl Acad Sci U S A 1997; 94:8878-8883.

30 van Aggel Leijssen DPC, van Baak MA, Tenenbaum R, et al. Regulation of average $24 \mathrm{~h}$ human plasma leptin level: the influence of exercise and physiological changes in energy balance. Int J Obes Relat Metab Disord 1999; 23:151-158.

31 Thong FS, Hudson R, Ross R, et al. Plasma leptin in moderately obese men: independent effects of weight loss and aerobic exercise. Am J Physiol Endocrinol Metab 2000; 279:E307-E313.

32 Pasman WJ, Westerterp-Plantenga MS, Saris WH. The effect of exercise training on leptin levels in obese males. Am J Physiol Endocrinol Metab 1998; 274:E280-E286.

33 Hilton LK, Loucks AB. Low energy availability, not exercise stress, suppresses the diurnal rhythm of leptin in healthy young women. Am J Physiol Endocrinol Metab 2000; 278:E43-E49.

34 Hukshorn CJ, Westerterp-Plantenga MS, Saris WH. Pegylated human - recombinant leptin (PEG-OB) causes additional weight loss in severely energy-restricted, overweight men. Am J Clin Nutr 2003; 77:771-776.

This clinical trial was the first to study the effects of leptin administration during starvation.

35 Haynes WG, Morgan DA, Walsh SA, et al. Receptor-mediated regional sympathetic nerve activation by leptin. J Clin Invest 1997; 100:270-278.

36 Tang Christensen M, Havel PJ, Jacobs RR, et al. Central administration of leptin inhibits food intake and activates the sympathetic nervous system in rhesus macaques. J Clin Endocrinol Metab 1999; 84:711-717.

37 Hukshorn CJ, Menheere PP, Westerterp-Plantenga MS, Saris WH. The effect of pegylated human recombinant leptin (PEG-OB) on neuroendocrine adaptations to semi-starvation in overweight men. Eur J Endocrinol 2003 148:649-655.

38 Chan JL, Heist K, DePaoli AM, et al. The role of falling leptin levels in the neuroendocrine and metabolic adaptation to short-term starvation in healthy men. J Clin Invest 2003; 111:1409-1421.

Detailed study of the effects of leptin replacement during short-term starvation.

39 Rosenbaum M, Murphy EM, Heymsfield SB, et al. Low dose leptin administration reverses effects of sustained weight-reduction on energy expenditure and circulating concentrations of thyroid hormones. J Clin Endocrinol Metab 2002; 87:2391-2394.

40 Montague CT, Faroogi IS, Whitehead JP, et al. Congenital leptin deficiency is associated with severe early-onset obesity in humans. Nature 1997; 387:903-908.

41 Clement $\mathrm{K}$, Vaisse $\mathrm{C}$, Lahlou N, et al. A mutation in the human leptin receptor gene causes obesity and pituitary dysfunction. Nature 1998; 392:398-401.

42 Faroogi IS, Jebb SA, Langmack G, et al. Effects of recombinant leptin therapy in a child with congenital leptin deficiency. N Engl J Med 1999; 341:879-884

43 Strobel A, Issad T, Camoin L, et al. A leptin missense mutation associated with hypogonadism and morbid obesity. Nat Genet 1998; 18:213-215.

44 Coleman DL. Obesity genes: beneficial effects in heterozygous mice. Science 1979; 203:663-665. 
45 Chung WK, Belfi K, Chua M, et al. Heterozygosity for Lep(ob) or Lep(rdb) affects body composition and leptin homeostasis in adult mice. Am J Physio Regul Integr Comp Physiol 1998; 274:R985-R990.

46 Faroogi IS, Keogh JM, Kamath S, et al. Partial leptin deficiency and human adiposity. Nature 2001; 414:34-35.

47 Farooqi IS, Matarese G, Lord GM, et al. Beneficial effects of leptin on obesity, T cell hyporesponsiveness, and neuroendocrine/metabolic dysfunction of human congenital leptin deficiency. J Clin Invest 2002; 110:10931103.
48 Cochran E, Young JR, Sebring N, et al. Efficacy of recombinant methionyl - human leptin therapy for the extreme insulin resistance of the RabsonMendenhall syndrome. J Clin Endocrinol Metab 2004; 89:1548-1554.

First study to investigate the effect of leptin replacement in this particular syndrome.

49 Oral EA, Simha V, Ruiz E, et al. Leptin-replacement therapy for lipodystrophy. N Engl J Med 2002; 346:570-578.

50 Moran SA, Patten N, Young JR, et al. Changes in body composition in patients with severe lipodystrophy after leptin replacement therapy. Metabolism 2004; 53:513-519. 